medRxiv preprint doi: https://doi.org/10.1101/2021.01.09.21249189; this version posted January $11,2021$. The copyright holder for this preprint (which was not certified by peer review) is the author/funder, who has granted medRxiv a license to display the preprint in All rights reserved. No reuse allowed without permission.

\title{
1 Association of Visual Impairment with Brain Structure
}

2

3 Running title: VI and brain structure

4

5 Authors

6 Zhuoting Zhu, MD PhD ${ }^{*}$

7 Wenyi $\mathrm{Hu}, \mathrm{MBBS}^{1 *}$

8 Huan Liao, $\mathrm{MD}^{2}$

$9 \quad$ Danli Shi, $\mathrm{MD}^{3}$

10 Zachary Tan, MBBS ${ }^{4}$

11 Yifan Chen, BM BCh ${ }^{5}$

12 Xianwen Shang, $\mathrm{PhD}^{1,4}$

13 Yu Huang, MD $\mathrm{PhD}^{1}$

14 Xueli Zhang, $\mathrm{PhD}^{1}$

$15 \quad$ Yu Jiang, $\mathrm{MD}^{3}$

16 Wei Wang, $\mathrm{MD} \mathrm{PhD}^{3}$

17 Xiaohong Yang, $\mathrm{MD} \mathrm{PhD}^{1}$

18 Mingguang $\mathrm{He}, \mathrm{MD} \mathrm{PhD}^{1,3,4}$

\section{Affiliations}

21 1. Department of Ophthalmology, Guangdong Academy of Medical Sciences, 22 Guangdong Provincial People's Hospital, Guangzhou, China.

23 2. Neural Regeneration Group, Institute of Reconstructive Neurobiology, University 24 of Bonn, Bonn, Germany.

25 3. State Key Laboratory of Ophthalmology, Zhongshan Ophthalmic Center, Sun 26 Yat-sen University, Guangzhou, China.

27 4. Centre for Eye Research, University of Melbourne, East Melbourne, Victoria, $28 \quad$ Australia. 
medRxiv preprint doi: https://doi.org/10.1101/2021.01.09.21249189; this version posted January $11,2021$. The copyright holder for this preprint (which was not certified by peer review) is the author/funder, who has granted medRxiv a license to display the preprint in perpetuity.

All rights reserved. No reuse allowed without permission.

Oxford, UK.

31

32 Word count: Abstract, 266; Whole paper: 2275.

33 Tables: 3; Figures: 0; Supplement tables: 2.

34

35 Corresponding author

36 Mingguang $\mathrm{He}, \mathrm{MD} \mathrm{PhD}$

37 Email: mingguang.he@unimelb.edu.au

38 Xiaohong Yang, MD PhD

39 Email: syyangxh@scut.edu.cn

40 Wei Wang, MD PhD

41 Email:zoc_wangwei@yahoo.com

42

43

44

45

46

47

48

49

50

51

52

53

54

55

56

57

58 
medRxiv preprint doi: https://doi.org/10.1101/2021.01.09.21249189; this version posted January 11,2021 . The copyright holder for this preprint (which was not certified by peer review) is the author/funder, who has granted medRxiv a license to display the preprint in All rights reserved. No reuse allowed without permission.

60 Abstract

61 Objective

62 To investigate the association of visual impairment (VI) with brain structures in the 63 UK Biobank Study.

\section{Methods}

65 The UK Biobank Study is a large prospective study that recruited more than 500,000 66 participants aged 40-69 from 2006 to 2010 across the UK. Visual acuity (VA) of worse than 0.3 LogMAR units (Snellen 20/40) was defined as VI. Structural magnetic resonance imaging (MRI) data were obtained using a 3.0-T MRI imager. Volumetric measures of five global brain volumes (total brain volume, total grey matter, total white matter, cerebrospinal fluid (CSF), brain stem) and the volumes of seven specific brain region (thalamus, caudate nucleus, basal ganglia, pallidum, hippocampus, amygdala and nucleus accumbens) were included in the present analysis. Multivariable linear regression was used to investigate the association of VI with global and specific brain volumes.

\section{$75 \quad$ Results}

A total of 8976 participants free of neurological disorders at baseline assessment were included for the present analysis. The prevalence of VI was $0.02 \%(n=181)$. After adjusting for a range of cofounding factors, VI was significantly associated with decreased volumes of the total brain $(\beta=-0.12,95 \%$ confidence interval $(\mathrm{CI})-0.23$ to $0.00, \mathrm{P}=0.049)$, thalamus $(\beta=-0.16,95 \% \mathrm{CI}-0.18$ to $-0.04, \mathrm{P}=0.010)$, caudate nucleus $(\beta=-0.14,95 \% \mathrm{CI}-0.27$ to $0.00, \mathrm{P}=0.046)$, pallidum $(\beta=-0.15,95 \% \mathrm{CI}$ -0.27 to $-0.02, \mathrm{P}=0.028)$ and amygdala $(\beta=-0.18,95 \% \mathrm{CI}-0.31$ to $-0.04, \mathrm{P}=0.012)$. Interpretation

84 We found that VI is associated with a decrease in total brain volumes and the volumes of specific brain regions implicated in neurodegenerative diseases.

Key words: visual impairment, structural MRI, neurodegenerative diseases 
medRxiv preprint doi: https://doi.org/10.1101/2021.01.09.21249189; this version posted January 11,2021 . The copyright holder for this preprint (which was not certified by peer review) is the author/funder, who has granted medRxiv a license to display the preprint in All rights reserved. No reuse allowed without permission.

\section{Introduction}

91 Neurodegenerative diseases are a major cause of cognitive impairment and mortality 92 in the ageing populations ${ }^{1}$. The two most common neurodegenerative diseases, 93 Alzheimer's disease (AD) and Parkinson's disease (PD) affect nearly 50 million 94 people worldwide ${ }^{2,3}$. With the growth of the world population and the increase in life expectancy, the disease burden of neurodegenerative diseases is estimated to increase substantially in the near future. ${ }^{3,4}$ However, very few effective treatments for neurodegenerative diseases have been developed so $\operatorname{far}^{5}$, highlighting the importance of further investigating the underlying mechanisms of these diseases to facilitate the development of strategies for prevention and early detection.

As a projection of the central nerve system (CNS) via the optic nerve, the retina has been described as a "window to the brain"'. Additionally, growing evidence has reported strong associations of visual impairment (VI) with $\mathrm{AD}^{7}$ and $\mathrm{PD}^{8}$.

104 Nevertheless, the mechanisms underlying the associations between VI and 105 neurodegenerative diseases remains unknown. It has been widely recognized that structural changes in the brain could play important roles in the development and progression of neurodegenerative diseases ${ }^{9-12}$. Some studies have reported that structural changes in the brain, for example, decreased grey matter in the medial temporal lobe, may even precede the symptom onset of neurodegenerative diseases ${ }^{13 \text {, }}$ 14. Therefore, a better understanding of the relationship between VI and brain structure may provide insights into the mechanisms behind the associations between

112 VI and neurodegenerative diseases. To the best of our knowledge, no study to date has

113 investigated the association between VI and brain structure in the middle-aged and 114 elderly population.

116 Therefore, we aim to investigate the association of VI with brain structure in a 117 large-scale community-based study. 
medRxiv preprint doi: https://doi.org/10.1101/2021.01.09.21249189; this version posted January 11,2021 . The copyright holder for this preprint (which was not certified by peer review) is the author/funder, who has granted medRxiv a license to display the preprint in

All rights reserved. No reuse allowed without permission.

\section{Methods}

\section{Participants}

121 The UK Biobank is a large prospective study with more than 500,000 enrolled in

122 2006-2010 and participants 40 to 69 years of age attended one of 22 assessment

123 centers across the $\mathrm{UK}^{15}$. In late 2009, ocular assessments, including visual acuity

124 (VA), refraction, intraocular pressure (IOP), corneal hysteresis (CH), optical

125 coherence tomography (OCT) and fundus photography, were introduced to 6 centers

126 across the UK, taken by approximately 117,175 participants $^{16}$. In $2014,100,000$

127 original participants in the UK Biobank study were invited back for brain, heart and 128 body imaging ${ }^{17}$. Participants $(\mathrm{n}=9310)$ with both VA testing and structural brain MRI

129 available are included in the present study. For analysis of brain structure, a total of

130217 individuals with self-reported neurological disorders (Supplement Table 1) and

131117 with brain volumes of more than 4 standard deviations (SD) from mean values

132 were excluded, resulting in a final sample of 8976 participants for analysis.

\section{Standard protocol approvals, registrations, and patient consents}

135 Access to the UK Biobank data was granted after registration. The application ID was 136 62443. The UK Biobank has obtained Research Tissue Bank approval from its 137 Research Ethics Committee recommended by the National Research Ethics Service 138 (reference 11/NW/0382). Participants provided written informed consent.

\section{Visual Acuity Testing}

141 Participants were tested for habitual VA based on a logarithm of the minimum angle 142 of resolution (LogMAR) chart. The test was performed with participants at a distance

143 of 4 meters with optical correction, if any, or at 1 meter if not being able to read. The 144 right eye was measured first. Participants were asked to read the letter sequentially 145 from the top to the smallest-sized letter they could reliably identify. The test was 146 terminated if 2 letters were identified incorrectly and the total number of letters 147 correctly identified was converted to LogMAR VA ${ }^{16}$. VA worse than 0.3 LogMAR 148 units (Snellen 20/40) was defined as VI. 
medRxiv preprint doi: https://doi.org/10.1101/2021.01.09.21249189; this version posted January 11,2021 . The copyright holder for this preprint (which was not certified by peer review) is the author/funder, who has granted medRxiv a license to display the preprint in All rights reserved. No reuse allowed without permission.

\section{Structural MRI}

151 Structural MRI imaging data was obtained by a 3.0-T MRI imager (Siemens Skyra,

152 Siemens Healthcare, Erlangen, Germany) with a standard 32-channel radiofrequency 153 receiver head coil. T1-weighted structural imaging was performed in sagittal

154 orientation by using a three-dimensional magnetization-prepared rapid acquisition 155 with gradient echo sequence with a resolution of $1 \times 1 \times 1 \mathrm{~mm}$, a field-of-view of $156208 \times 256 \times 256$ matrix and a duration of 5 minutes ${ }^{17}$. The processing of initially 157 released data was performed by using FSL packages (the FMRIB Software Library, 158 Oxford, England). Structural imaging segmentation into grey matter, white matter and 159 cerebrospinal fluid (CSF) was applied by using FAST (Automated Segmentation Tool 160 in FMRIB) and subcortical structures were modelled by using FIRST (FMRIB's 161 Integrated Registration and Segmentation Tool) $)^{18}$. MRI protocols, imaging processing 162 and quality control are described in detail elsewhere ${ }^{17}, 18$. Data output by processing 163 pipeline were used in the present study. A total of five global brain volumes (total 164 brain volume, total grey matter, total white matter, CSF, brain stem) and volumes of 165 seven specific brain regions including thalamus, caudate nucleus, basal ganglia, 166 pallidum, hippocampus, amygdala and nucleus accumbens were included. Brain 167 volumes were standardized to z-scores.

\section{Covariates}

170 Factors known to be associated with brain structure were included as covariates in the 171 present analysis ${ }^{19-22}$, including age at baseline assessment, sex (male/female), 172 ethnicity (Caucasian and non-Caucasian), obtainable education (college or university 173 degree, and others), smoking status (current/previous and never), diabetes mellitus 174 (yes/no), hypertension (yes/no), major depression (yes/no) and body mass index 175 (BMI).

177 Age at baseline assessment was categorized into three groups: 40 to 49, 50 to 59, and 17860 to 69 years old. Diabetes was defined to include those participants who had 
medRxiv preprint doi: https://doi.org/10.1101/2021.01.09.21249189; this version posted January 11,2021 . The copyright holder for this preprint (which was not certified by peer review) is the author/funder, who has granted medRxiv a license to display the preprint in

All rights reserved. No reuse allowed without permission.

179 self-reported or doctor-diagnosed diabetes mellitus, were taking anti-hyperglycemic

180 medications or using insulin or had a glycosylated hemoglobin level of $\geq 6.5 \%$.

181 Hypertension was defined to include those participants who had self-reported, or

182 doctor-diagnosed hypertension, were taking antihypertensive drugs or had a systolic

183 blood pressure of at least $130 \mathrm{mmHg}$ or a diastolic blood pressure of at least 80

$184 \mathrm{mmHg}$ averaged over two measurements. Self-reporting and/or the score on the

185 Patient Health Questionnaire (PHQ, the first two items) of at least 3 were used to

186 identify participants with depression ${ }^{15}$. BMI was calculated as the weight in kilograms

187 divided by height in meters squared $\left(\mathrm{kg} / \mathrm{m}^{2}\right)$.

189 Statistical analysis

190 Baseline characteristics stratified by VI were reported as number and proportion for

191 categorical data, mean and standard deviation for continuous variables. Comparisons

192 of categorical variables were examined by chi-square test and continuous variables by

193 unpaired t-test. Multivariable linear regression was applied to model associations of

194 VI with total and specific brain volumes. We firstly adjusted for age and gender

195 (model I). The Benjamin-Hochberg procedure was employed to control the false 196 discovery rate (FDR) at the level of 5\%. Ethnicity, obtainable education, smoking

197 status, diabetes mellitus, hypertension, major depression and BMI were further 198 adjusted for if the model I achieved FDR $<5 \%$ significance. To reduce the prominent 199 effect of ageing on brain structure, we performed sensitivity analysis controlling for 200 age as a continuous variable and investigated the non-linear effects of age with 201 adjustments of age and age squared. Analyses were performed using Stata version 13 202 (version 14.0; StataCorp).

\section{Data Availability Statement}

205 All bona fide researchers could apply to UK Biobank resources for health-related 206 research with benefit to public health. (see ukbiobank.ac.uk/register-apply). 
medRxiv preprint doi: https://doi.org/10.1101/2021.01.09.21249189; this version posted January 11,2021 . The copyright holder for this preprint (which was not certified by peer review) is the author/funder, who has granted medRxiv a license to display the preprint in

All rights reserved. No reuse allowed without permission.

\section{Study Sample}

210 The present analysis included a sample of 8976 participants free of neurological 211 disorders. The baseline characteristics of the participants are shown in Table 1. The 212 prevalence of VI was $0.02 \%(n=181)$. Visually impaired participants were more likely 213 to be older and of non-Caucasian ethnicity. There were no significant differences in 214 the proportion of gender, obtainable education, smoking status, diabetes mellitus, 215 hypertension, major depression and in the value of BMI between VI and non-VI 216 groups.

\section{Brain Structure}

219 Table 2 shows global brain volumes and the volumes of specific brain regions stratified by VI status. Except for the cerebrospinal fluid, visually impaired participants had lower volumes of other global and all specific regions of the brain.

\section{Association of VI with Brain Structure}

224 The associations of VI with multiple brain structures are reported in Table 3. The ageand gender-adjusted regression models demonstrated that VI was associated with lower volumes of the total brain $(\beta=-0.17,95 \%$ confidence interval (CI) -0.29 to $-0.05, \mathrm{P}=0.020)$, total grey matter $(\beta=-0.17,95 \% \mathrm{CI}-0.29$ to $-0.05, \mathrm{P}=0.021)$, total white matter ( $\beta=-0.16,95 \%$ CI -0.27 to $-0.04, P=0.021)$, brain stem $(\beta=-0.16,95 \%$ CI -0.28 to $-0.03, \mathrm{P}=0.021)$, thalamus $(\beta=-0.19,95 \% \mathrm{CI}-0.31$ to $-0.07, \mathrm{P}=0.020)$, caudate nucleus $(\beta=-0.17,95 \% \mathrm{CI}-0.30$ to $-0.03, \mathrm{P}=0.021)$, putamen nucleus $(\beta=$ $-0.16,95 \% \mathrm{CI}-0.28$ to $-0.03, \mathrm{P}=0.021)$, pallidum $(\beta=-0.18,95 \% \mathrm{CI}-0.31$ to -0.04 , $\mathrm{P}=0.021)$ and amygdala $(\beta=-0.20,95 \% \mathrm{CI}-0.34$ to $-0.06, \mathrm{P}=0.020)$. In the full-adjusted models, VI had significant negative associations with the volumes of the total brain $(\beta=-0.12,95 \%$ confidence interval $(\mathrm{CI})-0.23$ to $0.00, \mathrm{P}=0.049)$, thalamus $(\beta=-0.16,95 \% \mathrm{CI}-0.18$ to $-0.04, \mathrm{P}=0.010)$, caudate nucleus $(\beta=-0.14$, 95\% CI -0.27 to $0.00, \mathrm{P}=0.046)$, pallidum $(\beta=-0.15,95 \% \mathrm{CI}-0.27$ to $-0.02, \mathrm{P}=$ $0.028)$ and amygdala $(\beta=-0.18,95 \% \mathrm{CI}-0.31$ to $-0.04, \mathrm{P}=0.012)$. 
medRxiv preprint doi: https://doi.org/10.1101/2021.01.09.21249189; this version posted January 11,2021 . The copyright holder for this preprint (which was not certified by peer review) is the author/funder, who has granted medRxiv a license to display the preprint in

All rights reserved. No reuse allowed without permission.

\section{Sensitivity Analysis}

240 Sensitivity analysis controlling for age as a continuous variable was performed. The 241 significant associations of total brain volume or caudate volume with VI shown in the 242 main analysis had only marginal significance. With respect to volumes of other global 243 and specific regions, similar results to the main analysis were yielded (Supplement

244 Table 2). After further adjustments for squared age, the results continued to remain 245 similar (Supplement Table 2).

\section{Discussion}

248 In the present analysis, we found that visually impaired individuals had lower 249 volumes of total brain and multiple specific regions of brain structures, including the 250 thalamus, caudate nucleus, pallidum and amygdala. Our findings provide insights into 251 the mechanisms underlying the association between VI and neurodegenerative 252 diseases.

254 To the best of our knowledge, this is the first study to date to report the association of

255 VI with brain structure in the middle-aged and elderly participants. A previous study 256 investigated the effects of congenital VI on brain structure in children ${ }^{23}$. They found 257 defects in the development of the posterior tracts of the visual system and reduced 258 volume of the thalamus in children with congenital VI. Limited numbers of studies 259 have investigated the associations of ocular diseases with changes in brain 260 structure ${ }^{24-26}$. Patients with high myopia showed altered grey matter volumes in terms 261 of the visual pathway and limbic systems ${ }^{24}$. Wang et al. ${ }^{25}$ described altered brain 262 structure (visual and non-visual cortex, lateral geniculate body and amygdala) in 263 patients with glaucoma. Similarly, another study reported that the volume of the 264 lateral geniculate body was negatively associated with the cup-disc ratio ${ }^{26}$. Consistent 265 with previous findings, the present analysis observed atrophy of the visual pathway 266 (thalamus) and limbic systems (amygdala) in the visually impaired participants. 267 Intriguingly, atrophy of pallidum and caudate, which have well-established roles in motor regulation, was also observed in participants with VI. Study population (e.g., 
medRxiv preprint doi: https://doi.org/10.1101/2021.01.09.21249189; this version posted January 11,2021 . The copyright holder for this preprint (which was not certified by peer review) is the author/funder, who has granted medRxiv a license to display the preprint in

All rights reserved. No reuse allowed without permission.

269 age range, ethnic background, sociodemographic characteristics), study design, and 270 statistical analysis (e.g., statistical model, covariates adjusted in the model) might 271 explain the discrepancy in results between our study and previous studies.

273 Although the mechanisms behind the association between VI and brain atrophy are 274 not clear, several proposed mechanisms may provide explanations. It has been 275 indicated that the pathogenesis of neurodegenerative diseases could affect both 276 peripheral visual pathways and brain structure ${ }^{27,28}$. The reduced brain volume in the 277 hub of the visual pathway, the thalamus, may support this hypothesis ${ }^{29,30}$. Besides, the 278 reduction in visual inputs due to VI requires significant cognitive reserve to 279 compensate for the impaired vision and hence may increase the cognitive burden, 280 which could subsequently increase the vulnerability of the brain to neurodegenerative 281 pathology. This hypothesis echoed the changes in brain structures implicated in the 282 etiology of cognitive impairment and neurodegenerative diseases (total brain, 283 amygdala, pallidum, caudate and thalamus) observed in visually impaired 284 participants ${ }^{28,31-37}$. Global brain atrophy has been widely observed in patients with 285 neurodegenerative diseases ${ }^{38}$. The amygdala is important in processing and enhancing 286 emotional memory and its atrophy explains the neuropsychological symptoms in AD 287 patients $^{39}$. Pallidum and caudate nucleus play important roles in the regulation of 288 voluntary movements. Atrophies of these regions have been observed in 289 neurodegenerative diseases characterized by predominantly motor symptoms, such as 290 Parkinson's disease and Huntington's disease $\mathrm{e}^{40,41}$.

292 Alternatively, the association between VI and brain atrophy may be mediated by 293 psychological dysregulations, such as depression and social isolation. Individuals with 294 VI were found to be at higher risks of depression and social isolation ${ }^{42,43}$. Indeed, 295 brain volume changes in regions related to cognitive function and emotional control 296 (e.g. hippocampus and amygdala) were previously reported in individuals with 297 depression and social isolation ${ }^{44,45}$. Although depression is the most important risk 298 factor for dementia and Parkinson's disease ${ }^{46,47}$, the changes in brain volumes 
medRxiv preprint doi: https://doi.org/10.1101/2021.01.09.21249189; this version posted January 11,2021 . The copyright holder for this preprint (which was not certified by peer review) is the author/funder, who has granted medRxiv a license to display the preprint in

All rights reserved. No reuse allowed without permission.

299 identified in the present study could not be entirely explained by depression, as the

300 association between VI and brain volume reduction remained significant after 301 adjusting for depression.

303 There are several strengths of our study, including the large-scale sample size,

304 comprehensive MRI data on the total brain and specific brain structures, subjective 305 measure of VA and comprehensive adjustments of confounding factors. However, our 306 study also has some limitations. Firstly, due to the cross-sectional design of the study, 307 we are unable to clarify the causality between VI and altered brain structures. Further 308 longitudinal studies are warranted to investigate the association between VI and the 309 progression of alterations in brain structure. Secondly, the participants recruited in the 310 UK biobank do not represent the whole sampling population due to "healthy 311 volunteer" selection bias $^{48}$. Nevertheless, the investigation of the association between 312 VI and brain structure does not require full representativeness and the results retain its 313 robustness. Lastly, residual confounding could not be completely excluded.

\section{Conclusion}

316 In conclusion, our study found that VI is associated with decreased volumes in the 317 total brain and specific brain regions that are related to neurodegenerative diseases. 318 Further studies are warranted to examine the longitudinal relationship between VI and 319 brain structure alterations.

320 Abbreviations and Acronyms:

$321 \quad$ VI = visual impairment; VA = visual acuity; $\mathbf{M R I}=$ magnetic resonance imaging;

322 CNS $=$ central nervous system; $\mathbf{A D}=$ Alzheimer's disease $; \mathbf{P D}=$ Parkinson's disease;

$323 \mathbf{C S F}=$ cerebrospinal fluid; $\mathbf{B M I}=$ body mass index; $\mathbf{I O P}=$ intraocular pressure, $\mathbf{C H}$ $324=$ corneal hysteresis; OCT $=$ optical coherence tomography; $\mathbf{S D}=$ standard deviation; 325 FDR $=$ false discovery rate; PHQ $=$ Patient Health Questionnaire; LogMAR = 326 logarithm of the minimum angle of resolution; $\mathbf{C I}=$ confidence intervals. 
medRxiv preprint doi: https://doi.org/10.1101/2021.01.09.21249189; this version posted January 11,2021 . The copyright holder for this preprint (which was not certified by peer review) is the author/funder, who has granted medRxiv a license to display the preprint in All rights reserved. No reuse allowed without permission.

328 Acknowledgements: The present work was supported by the Fundamental Research 329 Funds of the State Key Laboratory of Ophthalmology, Project of Investigation on 330 Health Status of Employees in Financial Industry in Guangzhou, China (Z012014075), 331 Science and Technology Program of Guangzhou, China (202002020049). Prof.

332 Mingguang He receives support from the University of Melbourne at Research 333 Accelerator Program and the CERA Foundation. The Centre for Eye Research 334 Australia receives Operational Infrastructure Support from the Victorian State 335 Government. The sponsor or funding organization had no role in the design or 336 conduct of this research.

\section{Author Contributions:}

339 Study concept and design: Zhu ZT, Hu WY, Liao H, He MG, Yang XH.

340 Acquisition, analysis, or interpretation: All authors.

341 Drafting of the manuscript: Zhu ZT, Hu WY.

342 Critical revision of the manuscript for important intellectual content: Tan Z, Chen YF,

343 Shi DL, Wang W, He MG, Yang XH.

344 Statistical analysis: Zhu ZT, Shang XW.

345 Obtained funding: He MG, Yang XH.

346 Administrative, technical, or material support: Zhu ZT, Shang XW, Wang W, He MG, 347 Yang XH.

348 Study supervision: Wang W, He MG, Yang XH.

350 Potential Conflicts of Interest: The author(s) have no potential conflicts of interest 351 in any materials discussed in this article. 
medRxiv preprint doi: https://doi.org/10.1101/2021.01.09.21249189; this version posted January 11,2021 . The copyright holder for this preprint (which was not certified by peer review) is the author/funder, who has granted medRxiv a license to display the preprint in

All rights reserved. No reuse allowed without permission.

\section{References}

354 1. Erkkinen MG, Kim MO, Geschwind MD. Clinical Neurology and Epidemiology

355 of the Major Neurodegenerative Diseases. Cold Spring Harb Perspect Biol 2018;10.

356 2. Collaborators GBDD. Global, regional, and national burden of Alzheimer's 357 disease and other dementias, 1990-2016: a systematic analysis for the Global Burden 358 of Disease Study 2016. Lancet Neurol 2019;18:88-106.

359 3. Collaborators GBDPsD. Global, regional, and national burden of Parkinson's 360 disease, 1990-2016: a systematic analysis for the Global Burden of Disease Study 361 2016. Lancet Neurol 2018;17:939-953.

362 4. Alzheimer's A. 2016 Alzheimer's disease facts and figures. Alzheimers Dement 363 2016;12:459-509.

364 5. Mangialasche F, Solomon A, Winblad B, Mecocci P, Kivipelto M. Alzheimer's 365 disease: clinical trials and drug development. Lancet Neurol 2010;9:702-716.

366 6. Liao H, Zhu Z, Peng Y. Potential Utility of Retinal Imaging for Alzheimer's 367 Disease: A Review. Front Aging Neurosci 2018;10:188.

368 7. Uhlmann RF, Larson EB, Koepsell TD, Rees TS, Duckert LG. Visual impairment 369 and cognitive dysfunction in Alzheimer's disease. J Gen Intern Med 1991;6:126-132.

370 8. Uc EY, Rizzo M, Anderson SW, Qian S, Rodnitzky RL, Dawson JD. Visual 371 dysfunction in Parkinson disease without dementia. Neurology 2005;65:1907-1913.

372 9. Przedborski S, Vila M, Jackson-Lewis V. Neurodegeneration: what is it and 373 where are we? J Clin Invest 2003;111:3-10.

374 10. Pini L, Pievani M, Bocchetta M, et al. Brain atrophy in Alzheimer's Disease and 375 aging. Ageing Res Rev 2016;30:25-48.

376 11. Calabrese M, Magliozzi R, Ciccarelli O, Geurts JJ, Reynolds R, Martin R. 377 Exploring the origins of grey matter damage in multiple sclerosis. Nat Rev Neurosci 378 2015; $16: 147-158$.

379 12. Sarasso E, Agosta F, Piramide N, Filippi M. Progression of grey and white matter 380 brain damage in Parkinson's disease: a critical review of structural MRI literature. J 381 Neurol 2020.

382 13. Smith CD, Chebrolu H, Wekstein DR, et al. Brain structural alterations before 383 mild cognitive impairment. Neurology 2007;68:1268-1273.

384 14. Smith CD, Andersen AH, Gold BT, Alzheimer's Disease Neuroimaging I. 385 Structural brain alterations before mild cognitive impairment in ADNI: validation of 386 volume loss in a predefined antero-temporal region. J Alzheimers Dis 2012;31 Suppl $387 \quad 3: \mathrm{S} 49-58$.

388 15. Sudlow C, Gallacher J, Allen N, et al. UK biobank: an open access resource for 389 identifying the causes of a wide range of complex diseases of middle and old age. $390 \quad$ PLoS Med 2015;12:e1001779.

391 16. Chua SYL, Thomas D, Allen N, et al. Cohort profile: design and methods in the 392 eye and vision consortium of UK Biobank. BMJ Open 2019;9:e025077.

393 17. Miller KL, Alfaro-Almagro F, Bangerter NK, et al. Multimodal population brain 394 imaging in the UK Biobank prospective epidemiological study. Nat Neurosci $395 \quad 2016 ; 19: 1523-1536$. 
medRxiv preprint doi: https://doi.org/10.1101/2021.01.09.21249189; this version posted January 11,2021 . The copyright holder for this preprint (which was not certified by peer review) is the author/funder, who has granted medRxiv a license to display the preprint in

All rights reserved. No reuse allowed without permission.

396

397

398

399

400

401

402

403

404

405

406

407

408

409

410

411

412

413

414

415

416

417

418

419

420

421

422

423

424

425

426

427

428

429

430

431

432

433

434

435

436

437

18. Alfaro-Almagro F, Jenkinson M, Bangerter NK, et al. Image processing and Quality Control for the first 10,000 brain imaging datasets from UK Biobank. Neuroimage 2018;166:400-424.

19. Hamer M, Batty GD. Association of body mass index and waist-to-hip ratio with brain structure: UK Biobank study. Neurology 2019;92:e594-e600.

20. Rosenberg J, Lechea N, Pentang GN, Shah NJ. What magnetic resonance imaging reveals - A systematic review of the relationship between type II diabetes and associated brain distortions of structure and cognitive functioning. Front Neuroendocrinol 2019;52:79-112.

21. Merz EC, He X, Noble KG, Pediatric Imaging N, Genetics S. Anxiety, depression, impulsivity, and brain structure in children and adolescents. Neuroimage Clin 2018;20:243-251.

22. Raji CA, Ho AJ, Parikshak NN, et al. Brain structure and obesity. Hum Brain Mapp 2010;31:353-364.

23. Bathelt J, Dale NJ, de Haan M, Clark CA. Brain structure in children with congenital visual disorders and visual impairment. Dev Med Child Neurol 2020;62:125-131.

24. Huang $\mathrm{X}, \mathrm{Hu} \mathrm{Y}$, Zhou F, et al. Altered whole-brain gray matter volume in high myopia patients: a voxel-based morphometry study. Neuroreport 2018;29:760-767.

25. Wang J, Li T, Sabel BA, et al. Structural brain alterations in primary open angle glaucoma: a 3T MRI study. Sci Rep 2016;6:18969.

26. Chen Z, Wang J, Lin F, Dai H, Mu K, Zhang H. Correlation between lateral geniculate nucleus atrophy and damage to the optic disc in glaucoma. J Neuroradiol 2013;40:281-287.

27. Hart NJ, Koronyo Y, Black KL, Koronyo-Hamaoui M. Ocular indicators of Alzheimer's: exploring disease in the retina. Acta Neuropathol 2016;132:767-787.

28. Dallaire-Theroux C, Callahan BL, Potvin O, Saikali S, Duchesne S. Radiological-Pathological Correlation in Alzheimer's Disease: Systematic Review of Antemortem Magnetic Resonance Imaging Findings. J Alzheimers Dis 2017;57:575-601.

29. Benedict RH, Hulst HE, Bergsland N, et al. Clinical significance of atrophy and white matter mean diffusivity within the thalamus of multiple sclerosis patients. Mult Scler 2013;19:1478-1484.

30. Evangelou N, Konz D, Esiri MM, Smith S, Palace J, Matthews PM. Size-selective neuronal changes in the anterior optic pathways suggest a differential susceptibility to injury in multiple sclerosis. Brain 2001;124:1813-1820.

31. Apostolova LG, Beyer M, Green AE, et al. Hippocampal, caudate, and ventricular changes in Parkinson's disease with and without dementia. Movement Disorders 2010;25:687-695.

32. Kandiah N, Tan K, Lim CCT, Venketasubramanian N. Hyperglycemic choreoathetosis: Role of the putamen in pathogenesis. Movement Disorders 2009;24:915-919. 
medRxiv preprint doi: https://doi.org/10.1101/2021.01.09.21249189; this version posted January 11,2021 . The copyright holder for this preprint (which was not certified by peer review) is the author/funder, who has granted medRxiv a license to display the preprint in

All rights reserved. No reuse allowed without permission.

438

439

440

441

442

443

444

445

446

447

448

449

450

451

452

453

454

455

456

457

458

459

460

461

462

463

464

465

466

467

468

469

470

471

472

473

474

475

476

477

33. Azevedo CJ, Pelletier D. Whole-brain atrophy: ready for implementation into clinical decision-making in multiple sclerosis? Current Opinion in Neurology 2016;29:237-242.

34. Möller C, Dieleman N, van der Flier WM, et al. More Atrophy of Deep Gray Matter Structures in Frontotemporal Dementia Compared to Alzheimer's Disease. Journal of Alzheimer's Disease 2015;44:635-647.

35. Surova $Y$, Nilsson M, Lätt J, et al. Disease-specific structural changes in thalamus and dentatorubrothalamic tract in progressive supranuclear palsy. Neuroradiology 2015;57:1079-1091.

36. Mimuro M, Yoshida M. Chameleons and mimics: Progressive supranuclear palsy and corticobasal degeneration. Neuropathology 2019;40:57-67.

37. Eshaghi A, Marinescu RV, Young AL, et al. Progression of regional grey matter atrophy in multiple sclerosis. Brain 2018;141:1665-1677.

38. Mak E, Su L, Williams GB, et al. Longitudinal assessment of global and regional atrophy rates in Alzheimer's disease and dementia with Lewy bodies. NeuroImage: Clinical 2015;7:456-462.

39. Horinek D, Varjassyova A, Hort J. Magnetic resonance analysis of amygdalar volume in Alzheimer's disease. Curr Opin Psychiatry 2007;20:273-277.

40. Y Smith MDB, E Shink, J P Bolam. Microcircuitry of the direct and indirect pathways of the basal ganglia. Neuroscience 1998;86:353-387.

41. Bogaard SJA, Dumas EM, Acharya TP, et al. Early atrophy of pallidum and accumbens nucleus in Huntington's disease. Journal of Neurology 2010;258:412-420.

42. Cosh S, Hanno T, Helmer C, Bertelsen G, Delcourt C, Schirmer H. The association amongst visual, hearing, and dual sensory loss with depression and anxiety over 6 years: The Tromsø Study. International Journal of Geriatric Psychiatry 2017;33:598-605.

43. Coyle CE, Steinman BA, Chen J. Visual Acuity and Self-Reported Vision Status. Journal of Aging and Health 2016;29:128-148.

44. Pandya M, Altinay M, Malone DA, Anand A. Where in the Brain Is Depression? Current Psychiatry Reports 2012;14:634-642.

45. Düzel S, Drewelies J, Gerstorf D, et al. Structural Brain Correlates of Loneliness among Older Adults. Scientific Reports 2019;9.

46. Jorm AF. Is Depression a Risk Factor for Dementia or Cognitive Decline? Gerontology 2000;46:219-227.

47. Gustafsson H, Nordstrom A, Nordstrom P. Depression and subsequent risk of Parkinson disease: A nationwide cohort study. Neurology 2015;84:2422-2429.

48. Fry A, Littlejohns TJ, Sudlow C, et al. Comparison of Sociodemographic and Health-Related Characteristics of UK Biobank Participants With Those of the General Population. American Journal of Epidemiology 2017;186:1026-1034. 
medRxiv preprint doi: https://doi.org/10.1101/2021.01.09.21249189; this version posted January $11,2021$. The copyright holder for this preprint (which was not certified by peer review) is the author/funder, who has granted medRxiv a license to display the preprint in perpetuity.

All rights reserved. No reuse allowed without permission.

479

480 Table 1. Baseline Characteristics of Study Participants Stratified by Visual 481 Impairment Status.

\begin{tabular}{|c|c|c|c|c|}
\hline Baseline Characteristics & Total & VI Group & Non-VI Group & P Value \\
\hline $\mathrm{N}$ & 8976 & 181 & 8795 & - \\
\hline Age, No. (\%) & & & & 0.004 \\
\hline 40 to 49 & $2175(24.2)$ & $25(13.8)$ & $2150(24.5)$ & \\
\hline 50 to 59 & $3649(40.7)$ & $81(44.8)$ & $3568(40.6)$ & \\
\hline 60 to 69 & $3152(35.1)$ & $75(41.4)$ & $3077(35.0)$ & \\
\hline Gender, No. (\%) & & & & 0.205 \\
\hline Female & $4740(52.8)$ & $104(57.5)$ & $4636(52.7)$ & \\
\hline Male & $4236(47.2)$ & $77(42.5)$ & $4159(47.3)$ & \\
\hline Ethnicity, No. (\%) & & & & $<0.001$ \\
\hline Caucasian & $8525(95.0)$ & $161(89.0)$ & $8364(95.1)$ & \\
\hline Non-Caucasian & $451(5.02)$ & $20(11.1)$ & $431(4.90)$ & \\
\hline Educational Level, No. (\%) & & & & 0.964 \\
\hline College or university degree & $4230(47.1)$ & $85(47.0)$ & $4145(47.1)$ & \\
\hline Others & $4746(52.9)$ & $96(53.0)$ & $4650(52.9)$ & \\
\hline Smoking status, No. (\%) & & & & 0.521 \\
\hline Never/former & $5525(61.7)$ & $114(64.0)$ & $5411(61.7)$ & \\
\hline Current & $3425(38.3)$ & $64(36.0)$ & $3361(38.3)$ & \\
\hline BMI, mean (SD), $\mathrm{kg} / \mathrm{m}^{2}$ & $26.6(4.22)$ & $26.5(4.09)$ & $26.6(4.23)$ & 0.745 \\
\hline Diabetes mellitus, No. (\%) & & & & 0.957 \\
\hline No & $8672(96.6)$ & $175(96.7)$ & 8497 (96.6) & \\
\hline Yes & $304(3.39)$ & $6(3.31)$ & $298(3.39)$ & \\
\hline Hypertension, No. (\%) & & & & 0.833 \\
\hline No & $2664(29.7)$ & $55(30.4)$ & $2609(29.7)$ & \\
\hline Yes & $6312(70.3)$ & $126(69.6)$ & $6186(70.3)$ & \\
\hline Depression, No. (\%) & & & & 0.916 \\
\hline
\end{tabular}


medRxiv preprint doi: https://doi.org/10.1101/2021.01.09.21249189; this version posted January $11,2021$. The copyright holder for this preprint (which was not certified by peer review) is the author/funder, who has granted medRxiv a license to display the preprint in

All rights reserved. No reuse allowed without permission.

\begin{tabular}{llll}
\hline No & $8300(92.5)$ & $167(92.3)$ & $8133(92.5)$ \\
Yes & $676(7.53)$ & $14(7.73)$ & $662(7.53)$
\end{tabular}

Abbreviations: $\mathrm{VI}=$ visual impairment, $\mathrm{BMI}=$ body mass index, $\mathrm{SD}=$ standard deviation.

482

483 
medRxiv preprint doi: https://doi.org/10.1101/2021.01.09.21249189; this version posted January $11,2021$. The copyright holder for this preprint (which was not certified by peer review) is the author/funder, who has granted medRxiv a license to display the preprint in All rights reserved. No reuse allowed without permission.

484

485 Table 2. Brain Volume of Study Participants Stratified by Visual Impairment Status.

\begin{tabular}{|c|c|c|c|}
\hline Brain Volume ${ }^{a}$ & VI Group & Non-VI Group & P Value \\
\hline \multicolumn{4}{|l|}{ Global volume } \\
\hline Total brain volume & $-0.27(-0.41,-0.13)$ & $0.01(-0.02,0.03)$ & $<0.001$ \\
\hline Total grey matter & $-0.28(-0.42,-0.13)$ & $0.01(-0.02,0.03)$ & $<0.001$ \\
\hline Total white matter & $-0.23(-0.37,-0.09)$ & $0.00(-0.02,0.03)$ & 0.002 \\
\hline Brain stem & $-0.20(-0.34,-0.06)$ & $0.00(-0.02,0.02)$ & 0.008 \\
\hline Cerebrospinal fluid & $0.08(-0.07,0.23)$ & $-0.00(-0.02,0.02)$ & 0.300 \\
\hline \multicolumn{4}{|l|}{ Specific region volume } \\
\hline Thalamus & $-0.31(-0.45,-0.17)$ & $0.01(-0.01,0.03)$ & $<0.001$ \\
\hline Caudate nucleus & $-0.22(-0.36,-0.08)$ & $0.00(-0.02,0.03)$ & 0.003 \\
\hline Putamen nucleus & $-0.26(-0.40,-0.11)$ & $0.01(-0.02,0.03)$ & $<0.001$ \\
\hline Pallidum & $-0.23(-0.37,-0.09)$ & $0.00(-0.02,0.03)$ & 0.002 \\
\hline Hippocampus & $-0.20(-0.34,-0.05)$ & $0.00(-0.02,0.02)$ & 0.007 \\
\hline Amygdala & $-0.23(-0.37,-0.09)$ & $0.00(-0.02,0.03)$ & 0.002 \\
\hline Nucleus accumbens & $-0.23(-0.37,-0.09)$ & $0.00(-0.02,0.03)$ & 0.002 \\
\hline
\end{tabular}


medRxiv preprint doi: https://doi.org/10.1101/2021.01.09.21249189; this version posted January $11,2021$. The copyright holder for this preprint (which was not certified by peer review) is the author/funder, who has granted medRxiv a license to display the preprint in All rights reserved. No reuse allowed without permission.

488

Table 3. Associations of VI with Brain Volume.

\begin{tabular}{|c|c|c|c|c|}
\hline \multirow[b]{2}{*}{ Brain Volume ${ }^{\text {a }}$} & \multicolumn{2}{|c|}{ Age- and Gender-Adjusted Model } & \multicolumn{2}{|c|}{ Multivariable Model $^{c}$} \\
\hline & $\beta(95 \% \mathrm{CI})$ & P Value ${ }^{b}$ & $\beta(95 \% \mathrm{CI})$ & P Value \\
\hline \multicolumn{5}{|l|}{ Global volume } \\
\hline Total brain & $-0.17(-0.29,-0.05)$ & 0.020 & $-0.12(-0.24,-0.00)$ & 0.049 \\
\hline Total grey matter & $-0.16(-0.29,-0.04)$ & 0.021 & $-0.11(-0.23,0.01)$ & 0.081 \\
\hline Total white matter & $-0.15(-0.27,-0.03)$ & 0.021 & $-0.12(-0.24,0.00)$ & 0.055 \\
\hline Brain stem & $-0.16(-0.29,-0.02)$ & 0.021 & $-0.12(-0.25,0.01)$ & 0.070 \\
\hline Cerebrospinal fluid & $0.03(-0.10,0.15)$ & 0.794 & - & - \\
\hline \multicolumn{5}{|l|}{ Specific region volume } \\
\hline Thalamus & $-0.20(-0.33,-0.07)$ & 0.020 & $-0.17(-0.29,-0.04)$ & 0.010 \\
\hline Caudate nucleus & $-0.16(-0.30,-0.03)$ & 0.021 & $-0.14(-0.28,-0.00)$ & 0.046 \\
\hline Putamen nucleus & $-0.16(-0.29,-0.03)$ & 0.021 & $-0.12(-0.25,0.01)$ & 0.062 \\
\hline Pallidum & $-0.17(-0.31,-0.03)$ & 0.021 & $-0.16(-0.29,-0.02)$ & 0.028 \\
\hline Hippocampus & $-0.13(-0.26,0.01)$ & 0.103 & - & - \\
\hline Amygdala & $-0.20(-0.34,-0.06)$ & 0.020 & $-0.18(-0.32,-0.04)$ & 0.012 \\
\hline Nucleus accumbens & $-0.14(-0.27,-0.00)$ & 0.086 & - & - \\
\hline \multicolumn{5}{|c|}{ a Brain volumes were standardized to z-scores. } \\
\hline \multicolumn{5}{|c|}{${ }^{\mathrm{b}}$ Corrected for multiple comparisons. } \\
\hline \multicolumn{5}{|c|}{ c Adjusted for age, sex, ethnicity, obtainable education, smoking status, diabetes mellitus, hypertension, } \\
\hline
\end{tabular}

